\title{
Analysis of Potential Carrying Capacity of Feed for Beef Cattle in Barru Regency, South Sulawesi Province, Indonesia
}

\section{Ikrar Moh Saleh, Siti Nurlaelah, Indrawirawan \\ Department of Socio economics, Faculty of Animal Science, Hasanuddin University.}

Correspondence Author: Ikrar Moh Saleh, Department of Socio economics, Faculty of Animal Science, Hasanuddin University. E-mail: ikrarm@yahoo.com

Received date: 11 March 2018, Accepted date: 25 May 2018, Online date: 28 May 2018

Copyright: (C) 2018 Ikrar Moh Saleh et al. This is an open-access article distributed under the terms of the Creative Commons Attribution License, which permits unrestricted use, distribution, and reproduction in any medium, provided the original author and source are credited.

\begin{abstract}
This study aimed to analyze the potential of beef cattle breeding support capacity.The research conducted in Lompo Tengah village, Tanete Riaja Sub-district, Barru District from October to November 2014. Type of research used was survey method. Data type used in this research was quantitative data and qualitative data. Sources of data used were primer data obtained from interviews, Focus Group Discussion (FGD) and GPS coordinates data and secondary data that were supporting data from related institutions. Data collection was observation and interview. Result of research indicate support capacity of Central Lompo livestock feed was still sufficient for the development of beef cattle with a mean of carrying capacity of 9,71 .
\end{abstract}

Key words: carrying capacity, beef cattle, feed, potential

\section{INTRODUCTION}

The availability of information data on the pattern of utilization of animal feed in a region of beef cattle breeding development is needed for investment purposes. To invest, at least a variety of plans are needed, including knowing the potential forage available. The availability of feed can be known by knowing how the pattern of cropping forages in a region. This is due to the differences in land topography and landscape in each region. This distinction makes suitable feeds grown differently from one another according to the conditions of the existing region

Cattle business for the success with the aim of extracting the potential of natural and human resources, shifting the typology of the livestock business, creating employment opportunities, and applying technology. A variety of missions, namely: (1) provide food from cattle, (2) empower human resource farms, (3) increase the income of farmers, (4) create jobs livestock, and (5) to preserve and utilize natural resources. Rice plants and the joint production of rice bran that can be utilized by cattle as cattle feed. Feed is a major component for the success of the cattle business [1],[2],[3]

Increasing the production of beef cattle is a triangular relationship between land, fodder, and livestock. It is accordance [4] said every farmer has a business capacity which depends on land, capital, livestock ownership and management systems that lead to different revenues. Land is a place of life for livestock and as a forage producer of fodder. Therefore, to achieve an optimum production increase, knowledge of appropriate land use for animal feed is required to ensure adequate quantity and quality of feed.

Barru Regency became the center for the development and refining of beef cattle nationally, especially the type of Bali cattle. This district has great potential for the development of beef cattle; this is supported from the land area as forage forage area of 58,120 Ha and 4,813 Ha of pasture [5]. [6] Suggests that the District Barru is a good area to serve as a place for the development of beef cattle. This is because of the carrying capacity of climate suitability. One of the districts that have the largest population of beef cattle in Barru district is TaneteRiaja sub-district. Based on Table 1, we can see that the livestock population of Barru cattle per district in the last three years has always increased from year to year.

Table 1: Beef cattle population in Barru District (tail).

\begin{tabular}{|c|c|c|c|c|c|c|}
\hline \multirow[t]{2}{*}{ No } & \multirow[t]{2}{*}{ District } & \multicolumn{5}{|l|}{ Year } \\
\hline & & 2009 & 2010 & 2011 & 2012 & 2013 \\
\hline 1 & Tanete Riaja & 11.417 & 11.615 & 10.161 & 11.664 & 11.874 \\
\hline 2 & Pujananting & 9.450 & 10.100 & 9.373 & 10.038 & 10.985 \\
\hline 3 & Tanete Rilau & 4.726 & 5.050 & 6.436 & 7.538 & 7.516 \\
\hline 4 & Barru & 6.985 & 7.575 & 10.285 & 12.170 & 12.918 \\
\hline 5 & Soppeng Riaja & 5.498 & 6.060 & 5.295 & 6.612 & 6.189 \\
\hline 6 & Balusu & 4.490 & 4.545 & 4.964 & 5.815 & 5.830 \\
\hline 7 & Mallusetasi & 4.771 & 5.555 & 6.365 & 7.375 & 7.443 \\
\hline \multicolumn{2}{|c|}{ Added } & 47.337 & 50.501 & 52.879 & 61.212 & 62.035 \\
\hline
\end{tabular}

Source: Secondary data from the breeding service of the Regency of Barru, 2011.

Barru Regency has a height between 0-1.700 meters above sea level with the surface form of most of the slope, hilly to mountainous and some of the other areas are flat high ramps (BPS Barru District, 2013). In addition, in the region also flowed by several rivers. In Tanete Riaja sub-district, it is the largest river, the Sikapa River that flows through the rice fields and empties into the Makassar Strait [7].

The village of Lompo Tengah is one of the villages in Tanete Riaja sub-district. This region has the potential of forage resources for the development of beef cattle. Nevertheless, the available feed potential in Lompo Tengah village is not yet known for its carrying capacity of the existing beef cattle population. Feed 
material that has potential can be utilized as cattle feed in Central Lompo village is agricultural waste and grass cultivation of elephant grass. Potentials need to be known to determine the ability of the region in supplying feed. An analysis of the potential of carrying capacity can be used to find out how it is likely to develop beef cattle in the region in the future. Based on the previous description, a research aimed to calculate the carrying capacity of forage related to availability.

\section{Research Methodology:}

The research was carried out in Lompo Tengah village, Tanete Riaja Sub-district, Barru District from October to November 2014. This area was chosen as a research location on the consideration that this area is a centre of breeding and development of pure Bali cattle nationally so that researchers take the initiative to see the potential power support the feed and feed technology needs of beef cattle ranchers from the area. The type of research used is survey method. The survey was conducted to find out the potential of forage feed in the form of forage cultivation (elephant grass) and food crop waste (rice straw) which was analyzed based on study of study result and secondary data available. The type of data used in this study is quantitative data is data in the form of numbers and qualitative data is the response of the breeders on the technology of forage processing in accordance with their needs. Sources of data used are primary data is data obtained from interviews Focus Group Discussion (FGD) and GPS coordinates data and secondary data that is supporting data from institutions related to research and from previous research results related to the number of production conversion rice straw waste and dry elephant grass material production. Secondary data include data from the Animal Husbandry Service of Barru District, Central Bureau of Statistics of Barru Regency, RPJM of Lompo Tengah Village, and extensive data of grassland of livestock grazing. Data collection method is observation that is data collection through direct observation to the condition of research location in the form of topography and landscape, focus group discussion interview (FGD). Conducted focus group discussion, which is conducting focus group discussions with farmers to dig deeper and identify the actual conditions and problems of feed that occurred and data collection location (coordinates) research using GPS Coordinate data of research location is needed for data processing in geographic information system so that it can know the physical condition of region such as data of slope of area and land use map. The data analysis used is descriptive statistic by analysing the forage potential of forage feed. Analysis of the forage potential of livestock feed is done by calculating the feeding carrying capacity index of each hamlet in Lompo Tengah village.

The potential carrying capacity of the feed can be calculated using the formula as in[8]

Transport capacity $(\mathrm{ST})=$

Production of dry ingredient $(\mathrm{Kg})$

Need the dry ingredient of the adult cow (Kg/ST)

IDD value calculated based on BKC with equation as proposed by[9] is as follows:

[9] further explains that based on the value of the forage IDD, the condition criterion of the bearing capacity is obtained, which can be seen in Table 2 below:

\begin{tabular}{|l|l|} 
Transport capacity $=$ & Indeks Total production of dry digestion $(\mathrm{Kg})$ \\
$\sum$ Population Ruminansia x Needs BKC Adult Cow $(\mathrm{Kg} / \mathrm{ST})$
\end{tabular}

Table 2: State Criteria for IDD based forage.

\begin{tabular}{|l|l|l|}
\hline No. & IDD & criteria \\
\hline 1. & $\leq 1$ & Very critical \\
\hline 2. & $>1-1,5$ & critical \\
\hline 3. & $>1,5-2$ & vulnerable \\
\hline 4. & $>2$ & safe \\
\hline Source: $[9]$ & & \\
\hline
\end{tabular}

Source:[9].

[10] then explained about each IDD value have the following meanings:

a. $\quad$ Value $\leq 1$ :

Livestock has no choice in utilizing available resources

Resource extraction in its agro-ecosystem

There is no natural forage or waste that re-cycle

b. Value> $1-1.5$ :

Livestock has had the option to utilize resources but has not yet fulfilled the conservation aspect.

c. Value> $1.5-2$ :

Development of organic material to nature barely

d. Value> 2:

- The availability of functional feed resources to meet the needs of the environment efficiently.

To calculate the carrying capacity of feed in the research area in the form of rice straw and elephant grass (Pennisetumpurpureum), then used Table 3 forage characteristics of the existing feed. The production value of dry matter (BK ton / ha) from feed multiplied by the area of land for cultivation of rice and elephant grass then multiplied again with total harvest in a year.

Based on the identification in the field, the average of rice harvest in Lompo Tengah village in a year is 2 times, except Alakkangnge village only harvest paddy once a year. For elephant grass from planting age to harvest in a year can be done 5 times.

Table 3: Forage characteristics Lompo Tengah village.

\begin{tabular}{|l|l|l|}
\hline No & Type of Forage Animal Feed & Production BK (ton/ha/harvest) \\
\hline 1 & Rice straw & $5,94^{*}$ \\
\hline 2 & Elephant grass & $5,23^{* *}$ \\
\hline
\end{tabular}

Source: * [11].

$* *[12]$

\section{RESULTS AND DISCUSSION}

Potential Carrying Capacity Forage Feed:

The area of harvest and the production potential of paddy and elephant grass wastes in Lompo Tengah village can be seen in Table 8. The area of cattle feed harvest which has the potential of providing high feed material is Lisu hamlet which has total harvest area for feed forage of $453,3 \mathrm{Ha}(53.37 \%)$ 
Citation: Ikrar Moh Saleh et al., 2018. Analysis of Potential Carrying Capacity of Feed for Beef Cattle in Barru Regency, South Sulawesi Province, Indonesia. Advances in Environmental Biology., 12(5): 12-16.

Table 4: Animal feed collection areLompo Tengah Village

\begin{tabular}{|l|l|l|l|l|l|}
\hline \multirow{2}{*}{ No } & Hamlet & Large (Ha) & Total & Percentage \\
\cline { 3 - 7 } & & Rice fields & elephant grass gardens & $\%$ \\
\hline 1 & Ele & 40 & 15 & 55 & 6,48 \\
\hline 2 & Botto-botto & 60 & 75 & 435 & 15,89 \\
\hline 3 & Lisu & 255,8 & 197,5 & 453,3 & 53,37 \\
\hline 4 & Botto Lampe & 46,56 & 100,7 & 147,26 & 17,34 \\
\hline 5 & Alakkangnge & 46,82 & 10 & 58,82 & 6,93 \\
\hline Total & & 451,18 & 398,2 & 849,38 & 100 \\
\hline
\end{tabular}

Source: Secondary data processed, 2014

Table 4.illustrates the area of feed forage harvest area in Lompo Tengah village. The hamlet that has the most elephant grass harvest area is Lisu hamlet which is $197.5 \mathrm{Ha}$. The topography of the Lisu hamlet is partly surrounded by river banks [7]. River banks are utilized as a whole by farmers to grow elephant grass. As for the Alakkangnge region has the characteristics of different areas ie in the form of a mountain so that the development of elephant grass hampered drought in the dry season

Table 5: Feeding potential of dry matter production (BK) Lompo Tengah Village.

Table 5: Feeding potential of dry matter production (BK) Lompo Tengah Village.
\begin{tabular}{|l|l|l|l|l|l|}
\hline No & Dusun & Production BK feed (ton/year) & Total & Percentage \\
\cline { 3 - 7 } & & Rice fields & elephant grass gardens & 316,04 & 7,23 \\
\hline 1 & Ele & 237,6 & 78,44 & 748,61 & 17,12 \\
\hline 2 & Botto-botto & 356,4 & 392,21 & 2267,76 & 51,86 \\
\hline 3 & Lisu & 1234,93 & 1032,83 & 697,86 & 15,96 \\
\hline 4 & Botto Lampe & 276,57 & 421,29 & 342,29 & 7,83 \\
\hline 5 & Alakkangnge & 289,99 & 52,30 & $4.372,56$ & 100 \\
\hline Total & $2.395,48$ & $1.977,07$ & & \\
\hline
\end{tabular}

Source: Secondary data processed, 2014

Based on Table 5, it can be seen that total dry fodder production in Lompo Tengah village is 4,372.56 tonnes / year. The total production of dry matter is obtained from the quantity of dry matter produced between the rice straw and the elephant grass. The area that produces the most dry matter is the hamlet of Lisu, which provides $51.86 \%$ of the total dry fodder production for the village of Lompo Tengah. The high production of dry material in the hamlet of Lisu is correlated with the fodder forage area in the sub-village, which is $51.09 \%$ of the total fodder area.

The hamlet of Lisu has a high production of dry matter for cattle feed because it has a large area of paddy fields (127.9 Ha) and an elephant grass area (39.5 $\mathrm{Ha}$ ) wider than the others areas. In addition, in the hamlet of Lisu for rice harvest in a year is done twice. This is due to the support of the irrigation facilities and the existing pompanisasi system. The other hamlet that harvested it was done twice, Ele Village, Botto-botto and Botto Lamp hamlet. The DusunAlakkangnge rice crop is harvested once a year and most of the elephant grass belongs to the narrowest. This makes the production of dry ingredients for the feed of beef cattle which makes it the least compared to other hamlets.

Dry fodder production is determined by the area of the maupu rice straw planting area for elephant grass. Winugroho et al., In [11] explains that the availability of feed ingredients is also supported by the availability and production of agricultural crops in the form of waste and by-products, while the production agricultural products in addition affected by climatic conditions also influenced by the extensive cultivation of crops, labor and the number of cattle that are kept and the location of the agricultural area.

Feeding capacity Feeding feed cattle:

Feeding capacity is the capacity of the Lompo Tengah village area to produce grass derived food in the form of elephant grass and agricultural waste residues in the form of rice straw for the needs of the population. existing cattle. The feed availability analysis of feed is based on the load capacity and feed capacity index.

Table 6: Level of support capacity index for forage feed lompo Tenga village.

\begin{tabular}{|l|l|l|l|l|}
\hline Hamlet & Population (ST) & $\begin{array}{l}\text { Total Dry Material Production } \\
\text { (ton / yr) }\end{array}$ & Carrying capasity (ST) & $\begin{array}{l}\text { Indeks } \\
\text { Carrying capasity (IDD) }\end{array}$ \\
\hline Ele & 17,5 & 316,04 & 277,23 & 20,59 \\
\hline Botto-botto & 113,4 & 748,61 & 656,68 & 7,53 \\
\hline Lisu & 175,7 & 2267,76 & $1.989,26$ & 14,71 \\
\hline Botto Lampe & 204,4 & 697,86 & 612,15 & 3,89 \\
\hline Alakkangnge & 211,4 & 342,29 & 300,25 & 1,85 \\
\hline
\end{tabular}

Source: Secondary data processed, 2014

Table 6 above illustrates the livestock population (ST) data for each hamlet obtained from secondary data. The data are based on livestock units. The calculated data is multiplied by the conversion factor for beef cattle (0.7). The largest number of farmed cattle is in the village of Alakkangnge (211.4 ST).

The load capacity of the power supply (ST) is shown in Table 11. The hamlet of Ele has a load capacity of 277, 23 ST while the herd is very low at 17.5 ST. The hamlet Botto-Botto has a load capacity of 656.68 ST while the existing herd of 113.4 ST. The maximum carrying capacity of food is located in the hamlet of Lisu, which is $1,989.26 \mathrm{ST}$, while the available livestock is $175.7 \mathrm{ST}$. The carrying capacity of the smallest food is in the hamlet of Alakkangnge. This hamlet is only able to provide 300.25 ST food while the existing herd is 211.4 ST. The livestock population in the hamlet of Alakkkangnge is almost equal to the total carrying capacity of its feeding area compared to other hamlets.

Forage forage is the ratio of total forage availability to the total beef cattle population (ST) in an area. This value indicates the ability of an area to increase the number of livestock. From Table 6 , the forage load of each hamlet is not evenly distributed. The large difference in the low load capacity index of each hamlet can be known from the carrying capacity of each hamlet to accommodate a number of herds, as shown in Table 7.

Table 7: Support Feed of the Feed Condition of Animal Feed Lompo Tengah village.

\begin{tabular}{|l|l|l|l|}
\hline No & hamlet & index of carrying capacity (IDD) & Status \\
\hline 1 & Ele & 20,59 & Secure \\
\hline 2 & Botto-botto & 7,53 & Secure \\
\hline 3 & Lisu & 14,71 & Secure \\
\hline 4 & Botto Lampe & 3,89 & Secure \\
\hline 5 & Alakkangnge & 1,85 & Prone \\
\hline Average & 9,71 & Secure \\
\hline
\end{tabular}


Citation: Ikrar Moh Saleh et al., 2018. Analysis of Potential Carrying Capacity of Feed for Beef Cattle in Barru Regency, South Sulawesi Province, Indonesia. Advances in Environmental Biology., 12(5): 12-16.

Based on Table 7, one can see how the feed load capacity status feeds every hamlet of the village of Lompo Tengah. There are 4 villages namely Ele, Botto, Lisu and Botto lamp has a safe load capacity status means that food availability is functionally sufficient to livestock needs now living.

Four villages with a safe load capacity status is an indication that in the area, the availability of forage for food is able to meet the needs of the existing livestock. By calculation, the four hamlets for adding livestock are still possible. The highest load capacity index is in the hamlet of Ele, because the population of this hamlet beef is lowest. In addition, in this hamlet, the number of beef cattle farmers is the lowest compared to other hamlets. In general, the load capacity of foods is in the safe category. A hamlet whose feeding capacity is vulnerable, that is to say the hamlet of Alakkangnge.

The hamlet of Lisu has the second load capacity index (14.71) compared to the five existing hamlets. The value 14.71 is the ratio between the total feed availability and the number of head of cattle (ST) in the hamlet of Lisu. The availability of feed is supported by the larger area of the region compared to other hamlets. The potential for food availability comes from foods provided by the remaining agricultural products in the form of rice straw. DusunLisu is a hamlet with the largest area for agriculture in the form of the highest rice paddy (Table 10).

To explain between the interrelation of the carrying capacity of different foods to each other each hamlet can be seen in relation to time. Table 7 presents the season schedule in the village of Lompo Tengah. The hamlet is a mountain area which is the hamlet of Alakkangnge and part of the hamlet of Lisu is located in a flat area near the hamlet of Botto-botto, the hamlet of Ele and the hamlet of Botto Lampe.

Table 8: Calendar of the season Lompo Tengah village (month).

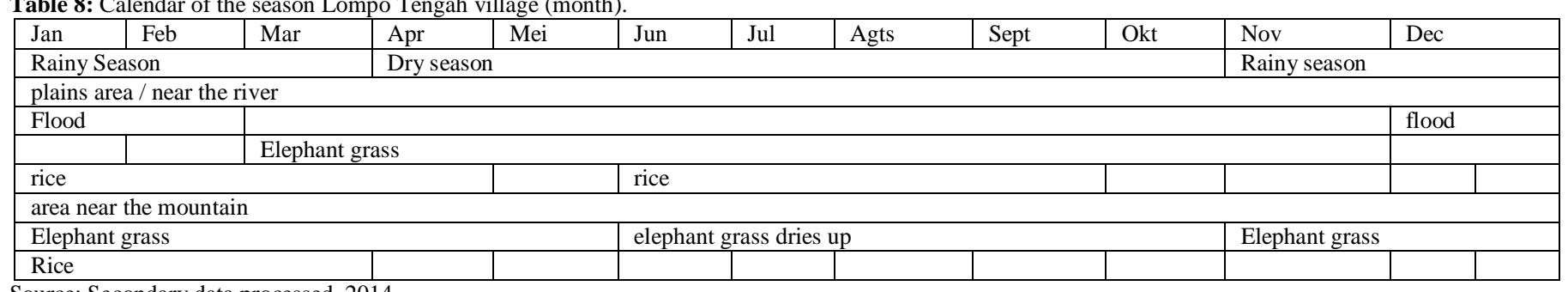

Source: Secondary data processed, 2014

The hamlet of Alakkangnge has a vulnerable carrying capacity. Vulnerability status means that availability of available food is low relative to the high population density of livestock (ST). In the calculation of the load capacity index, the hamlet of Alakkangnge is at number 1.85. Value of 1.85 is the result of dividing the total production of forage in the form of rice straw or grass that can be provided Alakkangnge hamlet year with the number of animals there. Farmers who are in the village of Alakkangnge in performing forage feed a lot of the grass they grow elephant grass. Elephant planting area in the hamlet of Alakkangnge is small, only 2 ha (see Table 8). In addition, the land area for a small elephant grass, in this hamlet for rice planting is only done once a year. Provision of growing grass (grass) and agricultural waste products (rice straw) cannot be used optimally to increase the number of animals that can be kept in the area. Rice planting is only done once because the existing rice paddy is a rainfed rice field. The water supply is heavily dependent on the rainy season. This season's condition and forage growing area from both agricultural products and narrow aquaculture make food availability reduced. [10] has argued in her research that livestock support capacity has chosen to use resources but has not fulfilled the conservation aspect.

In general, the central Lompo village in the food supply index is still in a safe status. By calculation, the average of the capacity index of each hamlet indicates the number of 9.71. This figure indicates that in the development of the population of beef cattle breeding, especially the addition of existing capacity is still possible to do the addition, it is because in some hamlets are widely available grass quite large. In addition, there is still a lot of potential agricultural waste in the form of rice straw that can be used to feed the animals.

From the table, we can see that on the calendar of the season, there are two seasons where each summer an impact on the availability of food from the cultivation of grass and foods derived from rice waste. In addition, regional topographic differences also affect food availability. In winter, between April and October, the availability of food varies according to the two topographic characteristics of the region. In the dry season power source obtained from the cultivation of grass plants in the diet of the area near the banks of the river, in front of the area near the mountains are not obtained the offer of this optimal area, the maximum can only be obtained once the harvest, because the lack of water resources for the grassland fertility area this, in addition to providing the grass culture feed , the dry season can also be obtained from agricultural waste such as rice seedlings were obtained from areas near the banks of the river.

In the rainy season, from Table 8.it can be explained that the rainy season from November to March. The availability of food in the period of the season can feed ddperoleh throughout the year, but it is the biggest obstacle facing the area along the river, the cultivated grass plants developed by the community in Muchdisebakancan not be harvested because of the flood. Unlike the mountainous region near the availability of food the cultivation of the grass can be achieved to the maximum because the water source for the plants of the grass that grows got well this season. Feeding sources from agricultural waste are easily obtained during this season because harvesting is maximized with the availability of adequate water sources.

Conclusion:

Load capacity (load capacity) of the central village Lompo forage is still sufficient for the development of beef cattle carrying the average index capacity of 9.71. However, if seen on the availability of food on each season has a difference. During the dry season, the availability of food that is based on different topographies, where the bank zone food availability of the crop grass (grass) and agricultural waste can meet the feed requirements, were in the area near the mountains of food availability of grass cultivation not optimal due to drought. During the rainy season, the availability of food along the river lower than the maximum area obtained as a result of the floods that occurred, while in the mountainous region near the maximum available for the grass to grow.

\section{REFERENCES}

[1] Sitti Nurani Sirajuddin, Aslina Asnawi, Sutomo Syawal, M. Jamal, 2016. Response of Cattle Breeders Silage in Soppeng Regency, South Sulawesi Province. American-Eurasian Journal of Sustainable Agriculture: 10(3): 33-36.

[2] Sitti Nurani Sirajuddin, Hastang, St. Rohani, M. Erik Kurniawan, 2016. Level Technology Adoption and Characteristic Cattle Breeders who following Bachelor Village Building. American-Eurasian Journal of Sustainable Agriculture, 10(5): 28-32.

[3] Sitti Nurani Sirajuddin, Ahmad Ramadhan Siregar, Palmarudi Mappigau, 2017. Adoption Rate of Beef Breeders Technology Following Partnership System in Barru Regency. American-Eurasian Journal of Sustainable Agriculture, 11(6): 31-34.

[4] Sitti Nurani Sirajuddin, Siti Nurlaelah, Amidah Amrawaty, Amrullah T., St. Rohani, Ikrar Moh.Saleh, 2017. Relationship Between Farmers Characteristic and Income from Beef Cattle with TheTraditional Profit-Sharing. American-Eurasian Journal of Sustainable Agriculture,11(5): 29-34.

[5] KPM3 Barru, 2013. Potential Investment Profile of the Regency of Barru. http://kp3mbarru.com/jdownloads/Potensi\%20Investasi/profil_daerah_dan_ potensi_investasi_kab_barru.pdf. access 25 September 2014.

[6] Supriadi, 2013. Profitability Analysis of Beef Cattle Marketing Facility in Tanete Riaja Sub-District. Skripsi. Fakultas Peternakan. Universitas Hasanuddin. Makassar.

[7] Rencana Pembangunan Jangka Menengah (RPJM) Desa Lompo Tengah tahun, 2011-2015. DesaLompo Tengah KecamatanTaneteRiaja, KabupatenBarru.

[8] Pitriani, L., 2011. Potential Area Producing Feed Supporting the Development of Cattle Population in Tanah Laut Regency. Thesis. Graduate School. Bogor Agricultural University. Bogor.

[9] Malau, M., 2007. Analysis of Land Resource Potential for Beef Cattle Development in Karo Regency. Tesis. Sekolah Pascasarjana. Institut Pertanian Bogor. Bogor. 
Citation: Ikrar Moh Saleh et al., 2018. Analysis of Potential Carrying Capacity of Feed for Beef Cattle in Barru Regency, South Sulawesi Province, Indonesia. Advances in Environmental Biology., 12(5): 12-16.

[10] Pelitawati, S., 2006. Analysis of the potential of land resources for the cattle development directive at Kabupaten Bangka. Tesis. Sekolah Pascasarjana. Institut Pertanian Bogor. Bogor.

[11] Syamsu, J.A., 2006. Analysis of the Waste Potential of Food Crops as Ruminant Feed Sources in South Sulawesi. Disertasi. Sekolah Pascasarjana. Institut Pertanian Bogor. Jawa Barat.

[12] Alfian, Y., F.I. Hermansyah, E. Handayanta, Lutojo, dan W.P.S. Suprayogi, 2012. Analysis of the efficiency of ruminant livestock farming in the dry season in the dryland farming area Semin District Gunungkidul Regency. Tropical Animal Husbandry, 1(1): 33-42. ISSN 2301-9921. 